\title{
COLONISATION OF THE UPPER RESPIRATORY TRACT OF MICE WITH GROUP B STREPTOCOCCI TYPE III WITH REFERENCE TO THE R-PROTEIN
}

\author{
D. N. Kurl** K. K. Christensen† AND P. Christensen $\ddagger$
}

* Department of Pathology, University of Cambridge, Cambridge CB2 12P and Departments of $\dagger$ Obstetrics and Gynecology and $\$$ Medical Microbiology, University of Lund, 22362 Lund, Sweden

\begin{abstract}
Summary. Nine strains of group B streptococci type III, five with $\mathrm{R}$-protein $(\mathrm{R}+)$ and four without $(\mathrm{R}-)$ were tested for capacity to colonise the upper respiratory tract in mice and to adhere to human buccal cells. In the mouse model, $80-\mu \mathrm{l}$ inocula of dilutions of overnight cultures of the strains in Todd Hewitt broth were placed in the external nares under light ether anaesthesia. A pilot experiment demonstrated that it was reasonable to study the throat colonisation 2 and 4 days after inoculation. Groups of 18-20 mice were then given inocula containing $8 \times 10^{6} \mathrm{cfu} / \mathrm{ml}$ of five $\mathrm{R}+$ and four $\mathrm{R}-$ strains. At day 4 , significantly more mice were colonised with type III, $\mathrm{R}+$ strains ( $73 \%$ of the animals) than with type III, $\mathrm{R}-$ strains $\left(44^{\%}\right)(\mathrm{p}<0.01)$. In adherence experiments with human buccal cells, no difference was found between the $\mathrm{R}+$ and $\mathrm{R}-$ strains. The results indicated that the higher colonisation rate among $\mathrm{R}+$ strains was mediated by mechanisms other than adherence.
\end{abstract}

\section{INTRODUCTION}

The occurrence of pneumonia in a high proportion of infants with neonatal septicaemia caused by group B streptococci (GBS) (Hemming, McCloskey and Hill, 1976) suggests that the upper respiratory tract is a possible portal of entry.

GBS from human sources are usually serotype Ia, Ib, Ic, II or III. There is evidence that the carbohydrate antigens of serotypes Ia, Ib, II and III are not implicated in the adherence of GBS to epithelial cells (Broughton and Baker, 1983). $\mathrm{R}$-protein can be detected in a large proportion of strains of types II and III isolated from clinical material, including blood-culture strains, but only rarely in type-I isolates (Lindén, Christensen and Christensen, 1983a). Furthermore, mouse-protection experiments (Lindén, 1983) and clinical studies (Lindén, Christensen and Christensen, $1983 b$ ) suggest that R-protein may be a virulence factor for some types of GBS.

Recent research has shown that the R-protein in GBS occurs on filamentous protrusions on the surface of the bacteria (Wagner et al., 1982), structures that might

Received 17 Oct. 1983; revised version accepted 15 Dec. 1983.

\footnotetext{
* Present address: Department of Medical Microbiology, Sölvegatan 23, S-223 62 Lund, Sweden.
} 
be important for attachment of bacteria to epithelial cells. Considering these factors and the possibility that proteins might be involved in adherence of GBS, we have studied the role of $\mathrm{R}$-protein in adherence using human buccal cells, and in colonisation of the upper respiratory tract in a mouse model.

\section{MATERIALS AND METHODS}

Streptococcal strains. The following strains of GBS type III, R-protein positive (III, R+) were used: D052, W25206, Ö2154, Ö2776 and Ö2021. Additionally, the R-negative GBS type III (III, R - ) strains W25403, W25190, 47 and D136C were studied. Except strain D136C (kindly supplied by the State Serum Institute, Copenhagen, Denmark), the strains were isolated at the Department of Clinical Bacteriology, Lund from cerebrospinal fluid or blood of neonates with GBS infections. Clinical isolates were grouped and typed serologically, and R-protein was detected, as previously described (Lindén et al., 1983a). None of the strains contained Ibc protein.

Animals. Female NMRI mice, 8 weeks old (weight 18-20 g) were purchased from Anticimex, Stockholm, Sweden. The animals were kept in cages in groups of 5-10 mice and given food and water ad libitum.

Intranasal inoculation of mice with GBS. The strains of GBS were grown overnight in $10 \mathrm{ml}$ of Todd Hewitt broth at $37^{\circ} \mathrm{C}$. Unless otherwise indicated, a 1 in 10 dilution in Todd Hewitt broth was used for intranasal inoculation of mice. Viable organisms were enumerated in each culture by plating $0.1-\mathrm{ml}$ volumes of the dilutions on blood agar; the average bacterial concentration in the 1 in 10 dilution was $10^{8} \mathrm{cfu} / \mathrm{ml}$. Each mouse was lightly anaesthetised with ether and then four drops $(80 \mu \mathrm{l})$ of inoculum were placed in the external nares with a Pasteur pipette.

In a pilot experiment, tenfold dilutions of strains D052 (type III, R +) and W25403 (type III, $\mathrm{R}-$ ), from $10^{8}$ to $10^{4} \mathrm{cfu} / \mathrm{ml}$ were used to inoculate mice (five animals for each bacterial preparation). Throat swabs (see later) were then taken from the animals on days $1,3,5,7,9,11$ and after 4 weeks to determine colonisation rates.

Throat swabs. Throat swabs were taken from the anaesthetised mouse by rotating a sterile disposable plastic loop thoroughly in the throat, without causing macroscopic damage to the mucosa. Specimens were inoculated directly on blood-agar plates and colonies of $\beta$-haemolytic streptococci were counted after overnight incubation of the plates at $37^{\circ} \mathrm{C}$. Randomly selected colonies were serologically grouped and typed. Cultures from non-inoculated mice contained no $\beta$-haemolytic colonies.

Adherence assays with human buccal cells. Buccal cells from four apparently healthy human beings were collected by scraping the buccal mucosa with sterile cotton swabs, and pooled in phosphate buffered saline (PBS). The same four individuals were used throughout the study and the cells collected on the day of each experiment. The adherence assays were performed according to the methods of Gibbons and van Houte (1971). Briefly, the buccal cells were washed three times in PBS by differential centrifugation. The concentration of the cells was then adjusted to $10^{5} / \mathrm{ml}$ after counting in a haemocytometer. The strains of GBS were grown as described above, washed three times in PBS and suspended to a concentration of $10^{8} \mathrm{cfu} / \mathrm{ml}$ in PBS. One $\mathrm{ml}$ of buccal cells and $1 \mathrm{ml}$ of GBS suspension were then mixed and rotated at 20 revolutions/min for $1 \mathrm{~h}$ at $37^{\circ} \mathrm{C}$. The mixture was washed four times with PBS by differential centrifugation $(3.4 \mathrm{~g})$. The cells were then spread on glass slides, dried in air and stained with crystal violet. The number of cocci sticking to 50 buccal cells was counted by microscopy in a blind fashion and the results presented as mean number of cocci per cell \pm standard error of the mean (SEM).

\section{RESULTS}

Colonisation of the upper respiratory tract of mice with two GBS type III strains. The capacities of strains D052 (GBS type III, R+) and W25403 (type III, R -) to colonise the upper respiratory tract of mice were studied by inoculation of tenfold 


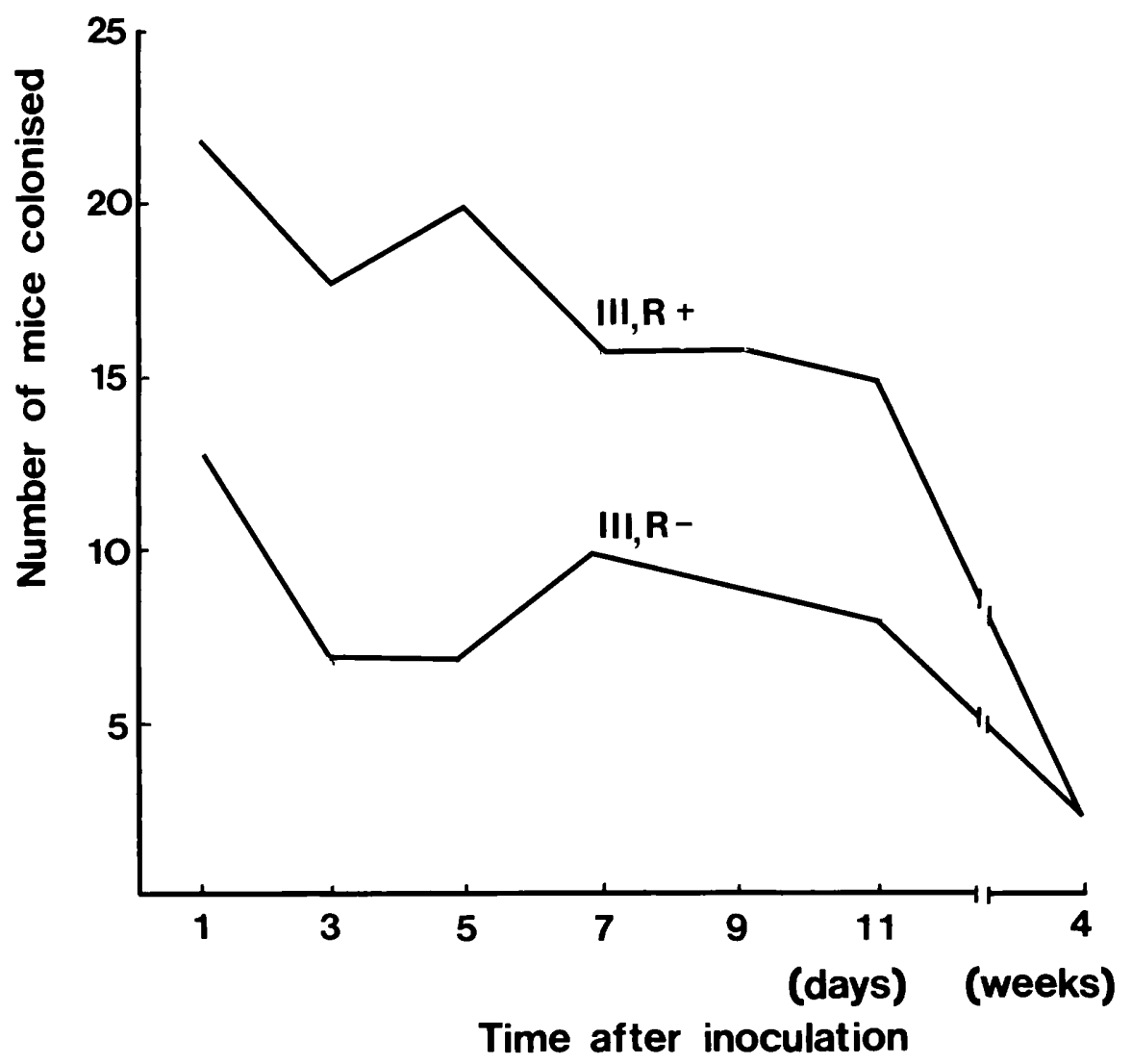

FIGURE - Colonisation of the upper respiratory tract of mice ( 25 animals for each strain) with GBS type III, $\mathrm{R}+$ (strain D052) and type III, R - (strain W25403).

dilutions of the strains, from $10^{8}$ to $10^{4} \mathrm{cfu} / \mathrm{ml}$. One animal, given strain D052, died from septicaemia; the others showed no sign of infection. There was no significant correlation between the number of cfu inoculated and the proportion of animals colonised. The results are, therefore, presented together for each strain (figure). On days 1,3 and 5 , the type III, $\mathrm{R}+$ strain colonised significantly more animals than the type III, $\mathrm{R}-$ strain ( $\mathrm{p}<0.05$; Chi-square test, exact method). Subsequently, no significant differences were found, and the number of animals colonised declined gradually. After 4 weeks only two animals in each group were colonised.

The number of GBS recovered from the throat swabs varied between 1 and $100 \mathrm{cfu}$ (mean 10). There was no significant difference between $\mathrm{R}+$ and $\mathrm{R}-\mathrm{GBS}$ in this respect. No changes with respect to type antigens and $\mathrm{R}$-protein were found among the randomly selected colonies investigated during the colonisation period.

Colonisation of the upper respiratory tract of mice with nine GBS type III strains with and without R-protein. Groups of 18-20 mice were given inocula containing $8 \times 10^{6}$ cfu of four type III, $\mathrm{R}-$ and five type III, $\mathrm{R}+\mathrm{GBS}$ strains. Cultures were taken from the throats at days 2 and 4 after the inoculation. On day 4 , between $32 \%$ and $65 \%$ 
TABLE

The capacity of type III, $R$ - and type III, R+ strains of GBS to colonise the upper respiratory tract of mice and to adhere to human buccal cells

\begin{tabular}{|c|c|c|c|}
\hline \multirow[b]{2}{*}{ Strains } & \multicolumn{2}{|c|}{$\begin{array}{l}\text { Number of mice col- } \\
\text { onised/Number of } \\
\text { mice inoculated }(\%) \\
\text { on }\end{array}$} & \multirow{2}{*}{$\begin{array}{l}\text { Number of bacteria } \\
\text { adhering to buccal } \\
\text { cells* }\end{array}$} \\
\hline & Day 2 & Day 4 & \\
\hline $\begin{array}{l}\text { Type III, R- } \\
\text { D136C } \\
\text { W25403 } \\
\text { W25190 } \\
47\end{array}$ & $\begin{array}{r}12 / 20(60) \\
7 / 19(37) \\
10 / 20(50) \\
6 / 19(32)\end{array}$ & $\begin{array}{r}13 / 20(65) \\
2 / 19(11) \\
13 / 20(65) \\
6 / 19(32)\end{array}$ & $\begin{array}{l}48 \pm 2 \cdot 5 \\
14 \pm 1 \cdot 4 \\
36 \pm 2 \cdot 7 \\
21 \pm 1 \cdot 7\end{array}$ \\
\hline $\begin{array}{l}\text { Type III, R+ } \\
\text { D052 } \\
\text { W25206 } \\
\text { Ö2154 } \\
\text { Ö2776 } \\
\text { Ö2021 }\end{array}$ & $\begin{array}{r}19 / 20(95) \\
15 / 18(83) \\
12 / 20(60) \\
15 / 19(79) \\
8 / 20(40)\end{array}$ & $\begin{array}{r}10 / 20(50) \\
17 / 18(94) \\
19 / 20(95) \\
17 / 19(89) \\
8 / 20(40)\end{array}$ & $\begin{array}{l}39 \pm 2 \cdot 4 \\
28 \pm 1 \cdot 4 \\
32 \pm 2 \cdot 3 \\
30 \pm 2 \cdot 3 \\
22 \pm 1 \cdot 7\end{array}$ \\
\hline
\end{tabular}

* Mean number of bacteria adhering to 50 cells \pm SEM

(mean $44 \%$ ) of the animals given the type III, R - strains were colonised whereas between $40 \%$ and $95 \%$ (mean $73 \%$ ) were colonised with the type III, $\mathrm{R}+$ strains ( $\mathrm{p}<0.01$, Chi-square test; Yates' correction; table).

Adherence of nine GBS type III strains with and without R-protein to human buccal cells. With the four type III, R - strains of GBS there were between 14 and 48 bacteria/cell (mean 30 bacteria/cell). The five type III, $R+$ strains gave 22-39 bacteria/cell (mean 30 bacteria/cell). Hence, there was no significant difference between type III, R + and type III, R - with respect to adherence to epithelial cells (table).

\section{DisCUSSION}

The results demonstrated that $\mathrm{R}+$ GBS type III strains colonise the upper respiratory tract of mice better than type III, R - strains (table). However, no difference was found between type III, $\mathrm{R}+$ and III, $\mathrm{R}$ - strains with respect to adherence to buccal cells. These results indicate that $\mathrm{R}$-protein is not important in adherence, but might be important in colonisation. Several factors influence colonisation by a microorganism in the present animal model. These include the capacity to adhere to epithelial cells, the ability to proliferate on the mucosal surface, and resistance to host defence mechanisms, e.g., removal by secretions and phagocytosis. Previous findings showed that rabbit anti- $\mathrm{R}$ protein antibodies protect against infection of mice with type II, R + GBS (Lindén, 1983); possibly R-protein enhanced colonisation by impairing phagocytosis.

In the present study we did not investigate type I strains because they rarely contain R protein (Jensen, 1980; Lindén et al., 1983a). Previous results have shown that $51 \%$ of type II and $87 \%$ of type III GBS strains isolated from neonates and from the urogenital tract of parturient women in Southern Sweden contain R-protein (Lindén et 
al., 1983a). Among the strains isolated from blood or cerebrospinal fluid of infected infants, one of two type II and 12 out of 14 type III strains contained R-protein (Lindén et al., 1983a). Jensen (1980) found R-protein in $93 \%$ of type III strains from the female urogenital tract in Denmark whereas Jelinkova (1977) reported that only $16 \%$ of human type III isolates in Czechoslovakia contained R-protein; the differences in results might be ascribable to mucosal adherence because the strains reported by Jelinkova were unselected. However, the present results clearly indicate that R-protein might contribute to the capacity of GBS type III to colonise the mucosal membranes.

We conclude that GBS type III, R+strains in general colonise the upper respiratory tract of mice more effectively than type III, $\mathrm{R}$ - strains. The reason for this higher colonisation capacity is not yet clear although $\mathrm{R}$-protein does not seem to be involved directly in the attachment of GBS to epithelial cells.

This work was supported by grant no. B83-16X-06559-01 from the Swedish Medical Research Council, the Expressens Prenatal Research Foundation, Allmänna BB's Minnesfond and the Medical Faculty, University of Lund. DNK was supported as a guest researcher by a Scholarship from the Swedish Institute.

\section{REFERENCES}

Broughton R A, Baker C J 1983 Role of adherence in the pathogenesis of neonatal group B streptococcal infection. Infection and Immunity 39:837-843.

Gibbons R J, van Houte J 1971 Selective bacterial adherence to oral epithelial surfaces and its role as an ecological determinant. Infection and Immunity 3:567-573.

Hemming V G, McCloskey D W, Hill H R 1976 Pneumonia in the neonate associated with group B streptotoccal septicemia. American Journal of Diseased Children 130:1231-1233.

Jelinkova J 1977 Group B streptococci in the human population. Current Topics in Microbiology and Immunology 76:127-165.

Jensen N E 1980 Serotypes of group B streptococci in urogenital patients. Scandinavian Journal of Infectious Diseases 12:101-104.

Lindén V 1983 Mouse-protective effect of rabbit anti-R-protein antibodies against group B streptococci type II carrying R-protein. Lack of effect in type III carrying protein. Acta Pathologica Microbiologica et Immunologica Scandinavica Section B 91:145-151.

Lindén V, Christensen K K, Christensen P 1983a The occurrence of R-protein among isolates of group B streptococci from human sources. Acta Pathologica Microbiologica et Immunologica Scandinavica Section B 91:153-156.

Lindén V, Christensen K K, Christensen P 1983b Correlation between low levels of maternal IgG antibodies to R-protein and neonatal septicemia with group B streptococci carrying R-protein. International Archives Allergy Applied Immunology 71:168-172.

Wagner B, Kubin V, Wagner M, Gunther E 1982 Immunoelectron microscopic analysis of polysaccharide and protein surface antigens in wild strains of group B streptococci. Zentralblatt für Bakteriologie, Hygiene und Immunologie 1 Abt Orig 253:331-343. 